\title{
SHAKING TABLE EXPERIMENTS ON MASONRY BUILDING PROTOTYPES PRODUCED WITH DIFFERENT BOND
}

\author{
${ }^{1}$ Fatih BAHADIR ${ }^{(\mathbb{D})}$, ${ }^{2}$ Fatih Süleyman BALIK \\ Necmettin Erbakan University, Eregli Kemal Akman High Vocational School, Eregli, Konya, TURKEY \\ ${ }^{1}$ fbahadir@erbakan.edu.tr, ${ }^{2}$ fsbalik@erbakan.edu.tr
}

(Geliş/Received: 09.12.2020; Kabul/Accepted in Revised Form: 14.01.2021)

\begin{abstract}
The major damages that occurred due to the earthquake are the formation of shear cracks and sliding cracks in the plane of the walls, the overturning of the walls out-of-plane, the separation of the walls from the corners and slabs. In this study, prototype masonry buildings were produced with different bonds $1 / 6$ geometric scale, one story and three-compartment were tested on the shaking table. These prototype masonry buildings were tested on a shaking table with sinusoidal dynamic testing. The walls of test specimens were produced with the cross, the flemish, the english, and the dutch bond, respectively. The behaviour of test specimens, displacement, elastic seismic loads were compared by giving the same ground motion to the specimens. Displacement measurements of the test specimens were made by the image processing method and acceleration data were measured by accelerometers. In the experimental studies, different types of failure modes and cracks that could occur during the earthquake were observed. In the shaking table, the maximum elastic seismic load has occurred at Specimen 4 (dutch bond). Because Specimen 1 had more rigid compared to the other specimens, Specimen 1 with cross bond also occurred the highest seismic performance. As a result, all masonry structures that are not carefully manufactured and do not receive engineering services, regardless of the type of the bond, cannot exhibit sufficient earthquake performance. As a result, for the masonry buildings stated in TBSC-2018, vertical lintels can be made on the sides of the door and windows, or the door and window spaces can be made smaller, which can make an important contribution to the seismic performance of masonry buildings.
\end{abstract}

Key Words: Shaking Table, Failure Mechanism, Masonry Buildings, Bond Type, Elastic Seismic Load, Response spectrum

\section{Farklı duvar örgüleri ile üretilmiş prototip yığma binaların sarsma tablası deneyleri}

ÖZ: Deprem nedeniyle meydana gelen en büyük hasarlar, duvar düzleminde kesme ve kayma çatlaklarının oluşması, duvarların düzlem-dışı dışı hareket etmesi, duvarların köşelerden ve döşemelerden ayrılmasıdır. Bu çalışmada, 1/6 ölçekli, tek katlı ve üç bölmeli farklı duvar örgüleri üretilmiş prototip yığma yapılar sarsma tablası üzerinde test edilmiştir. Bu prototip yığma yapılar sinüzoidal dinamik test ile sarsma tablasında test edilmiştir. Test numunelerinin duvarları sırasıyla haç, flamen, ingiliz ve hollanda tip örgüler ile üretilmiştir. Test numunelerinin davranışları, elastik sismik yükleri ve deplasmanları kıyaslayabilmek için numunelere aynı yer hareketi verilmiştir. Test numunelerinin yer değiştirme ölçümleri görüntü işleme yöntemi ile yapılmış ve ivme değerleri ivmeölçerler ile ölçülmüştür. Deneysel çalışmalarda deprem sırasında gözlemlenen, farklı tipte göçme modları ve çatlaklar meydana gelmiştir. Sallama tablasında, Numune 4'te (hollanda örgü) maksimum elastik sismik yük oluşmuştur. Numune 1 (haç örgü) diğer örneklere göre deneylerde daha rijit davrandığından dolayı, numune 1 en yüksek sismik performansı ulaşmıştır. Sonuç olarak, özenle imal edilmeyen ve mühendislik hizmeti almayan tüm yığma yapılar, örgü türü ne olursa olsun yeterli deprem performansı gösteremez. TBSC- 
2018'de belirtilen yığma binalarda kapı ve pencere kenarlarına düşey lentolar yapılabilir veya kapı ve pencere boşlukları küçültülebilir, bu da sismik performansına önemli katkı sağlayabilir.

Anahtar Kelimeler: Sarsma tablası, Göçme mekanizması, Yığma binalar, Örgü tipi, Elastik sismik yük, Tepki Spektrumu

\section{INTRODUCTION}

Masonry buildings are usually constructed using local materials in the rural area and without any engineering service. Therefore, it is possible to find a wide variety of materials and different workmanship in such buildings. As a result, uncertainty and difficulty arise in determining the safety of masonry buildings under earthquake loads. According to TBSC-2018 (Turkish Building Seismic Code, 2018), the maximum number of stories is 4 in Turkey. These buildings usually have hollow brick, briquettes and rarely mud-brick walls and reinforced concrete slabs. The large door and window openings located on the walls of these buildings and close to the corners constitute the weak points of the building.

Masonry buildings are generally quite stiff structures (e.g., a 4-story building usually has a natural vibration period of about $0.25 \mathrm{~s}$ ). Also, the damping ratios are quite low (about $1-2 \%$ of damping ratio). However, after the cracks arise, these damping ratios increase over the period. These structures may be damaged or even demolished during earthquakes within short periods. Lateral loads due to earthquakes in masonry structures are distributed to walls in the function of their rigidity, and shear cracks occur on the walls.

Strength in masonry structures is provided by adherence between brick and mortar. As the cracks created by the earthquake increase, the dynamic characteristics of the masonry buildings change, the natural frequency decreases and the displacements increase. As the lateral movement continues, the cracks are interrupted by vertical load and friction, forming independent wall blocks on the wall surface and the movement in the direction of the cracks increases. These cracks occur in regions with high-stress intensity. The cracks at the edge of the door and window are caused by the vertical bending to the wall plane or the shear stresses that occur in the plane direction. In long walls without door and window openings, these loads perpendicular to the wall plane form vertical or diagonal cracks in the horizontal cracks and wall joints in the lower region. The major damages encountered during the earthquake are the formation of shear cracks and sliding cracks in the plane of the walls, the overturning of the walls out-of-plane, the separation of the walls from the corners and slabs (Balendra, 1993, Arya et al., 2014). Different types of failure modes in walls of masonry buildings are shown in Figure 1.

Diagonal Shear Failure: Diagonal shear cracking caused by the maximum tension stress exceeding the tension strength of the wall. Diagonal shear cracks may occur in a stair-stepped manner through the bed-joints or may pass directly through the bricks. The separation of the walls from the joints into vertical or diagonal cracks is due to loads caused by the earthquake at perpendicular to the plane of the wall and the direction of the plane.

Bed-joint sliding - (Sliding failure) Sliding failure is caused by horizontal shear cracks in the bedjoint. When the loads coming from the wall plane exceeds the mortar strength between the bricks. These cracks are caused by the forces in the plane of the wall exceeding the strength of mortar between bricks. Generally, these cracks occur in the horizontal direction of the window and door corners.

Out-of-Plane Behaviour (Overturning): Because of earthquake loads, inertia forces are generated by the mass of the walls. The walls of masonry buildings perpendicular to the direction of the dominant earthquake are usually damaged by out-of-plane behavior. The cause of such damage is that the tops of the walls are not connected by a rigid slab, a ridge, or joists and beams. In times of earthquake, if there is insufficient resistance in the orthogonal walls, these walls push each other out of the plane at the corner, causing damage or even collapse of the walls.

Rocking: The rocking of the wall in the plane begins with the flexural cracks that develop in the upper and lower parts of the wall. As the displacement increases, the wall separating from the slab tries 
to rotate in a plane as a rigid body and eventually partially damages the toe region. Toe crushing is typically observed after rocking deformations.

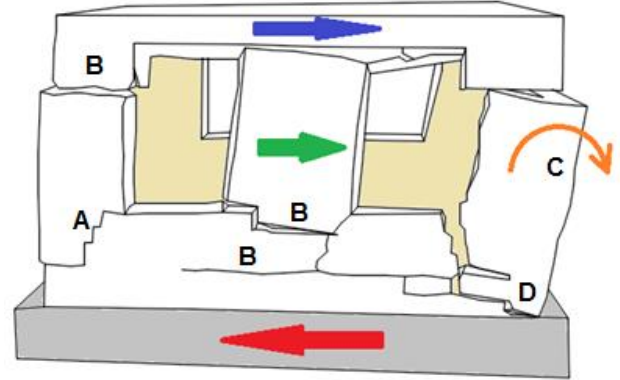

A. Shear crack B. Sliding crack C. Overturning D. Rocking

Figure 1. Failure mechanisms of masonry buildings.

Since 1960, shaking tables have been used for scientific research on earthquake and structural engineering studies (Stephen et al., 1969; Sullivan et al., 2004; Turer et al., 2007; Hanazato et al., 2008; Ersubasi and Korkmaz, 2010; Kamanli and Balik, 2010; Leite and Lourenco, 2012; Rao and Ramesh Babu, 2012; Saito et al., 2013; Başaran et al., 2014; Bahadir et al., 2018). In this study, prototype masonry buildings were produced $1 / 6$ geometric scale, one story and three-compartment were tested on the shaking table. Test specimens were produced with the cross, the flemish, the english, and the dutch bond, respectively. The behaviour of test specimens, displacement, elastic seismic loads were compared by giving the same ground motion to the specimens. Displacement measurements of the test specimens were made by the image processing method and acceleration value were measured by ADXL345 accelerometer. By using these values, it is aimed to make the related graphs and make comparisons.

\section{MATERIAL AND METHOD}

\subsection{Description of test specimens}

In this experimental study, four one-story, $1 / 6$ scaled, three-compartment masonry building prototypes were tested on the shaking table until the failure mode. Each prototype was built using a different bond type. The used bond types contained deficiencies commonly observed in residential buildings in Turkey. The experiments were manufactured and tested in the Structural Testing Laboratory at the Necmettin Erbakan University-Konya-TURKEY (Figure 2) (Balendra, 1993). All four tested specimens were produced with the same walls geometry and mortar. Specimen 1 was produced with the cross bond. Specimen 2 was produced with the flemish bond. Specimen 3 was produced with the english bond. Specimen 4 was produced with the dutch bond.

The height of one story was $450 \mathrm{~mm}$ (2700 $\mathrm{mm}$ in 1:1 scale real dimensions). The length of the specimen was $800 \mathrm{~mm}$ from one wall to another wall. The slab' dimensions were $800 \times 800 \mathrm{~mm}$ and $50 \mathrm{~mm}$ thickness. Dimensional of the specimens are shown Figure 3.

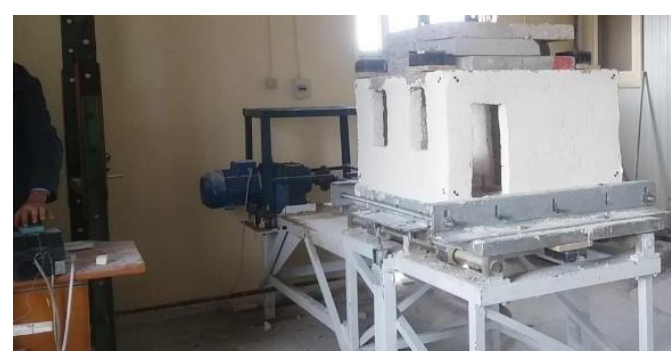

Figure 2. General photo of the test set-up for the experimental study 

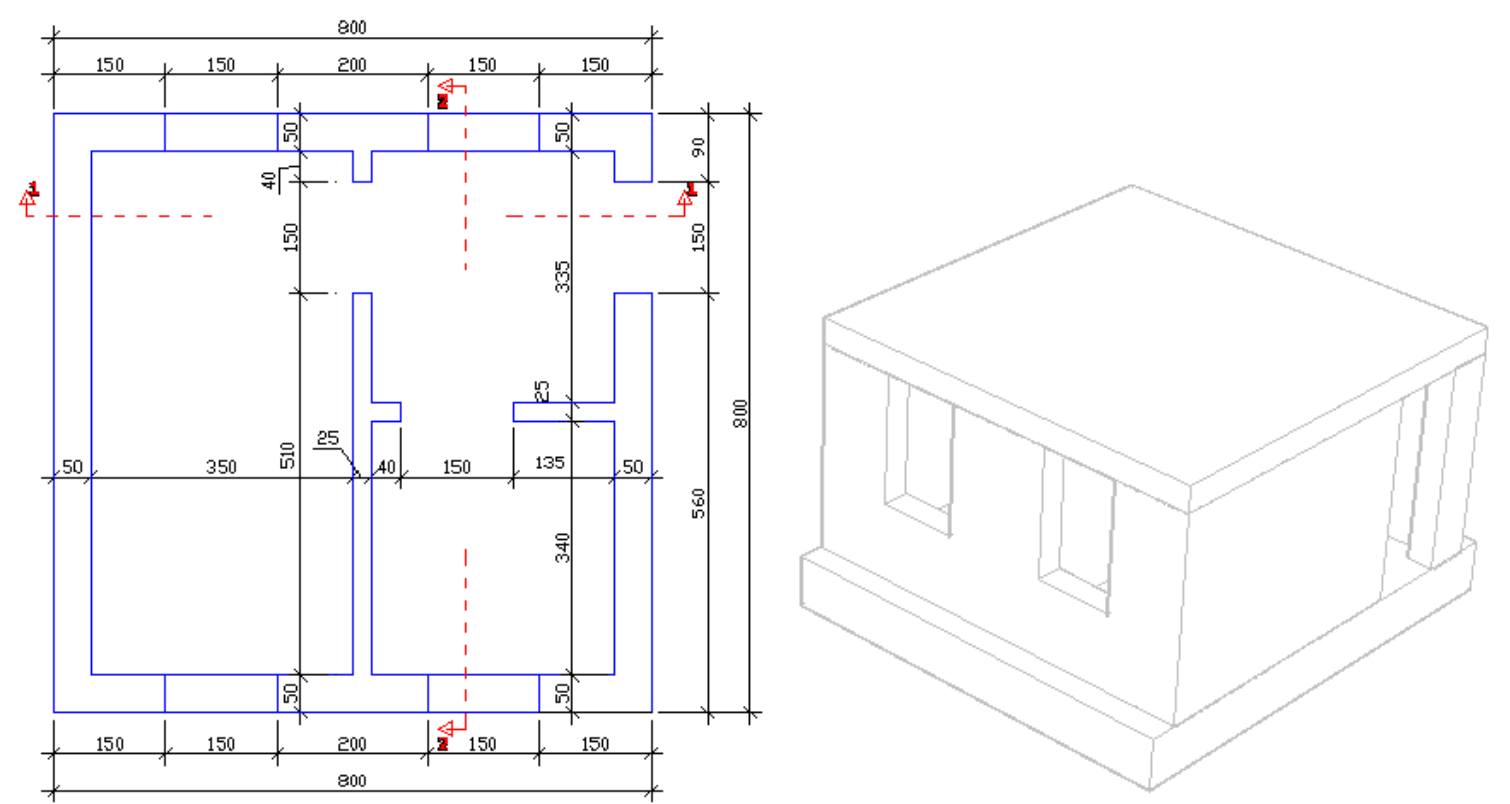

Plan

$3 \mathrm{D}$ view
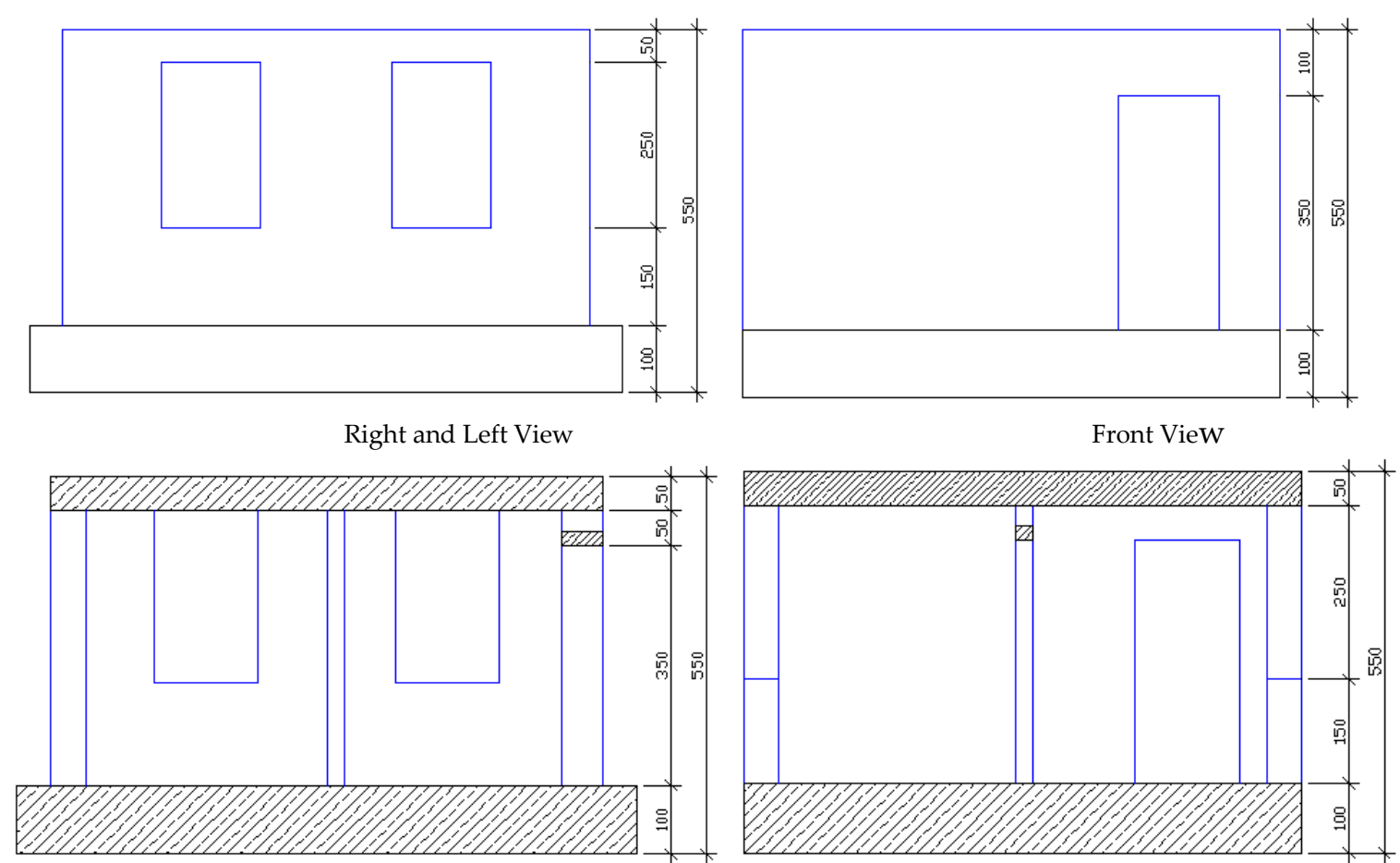

Section 1-1

Section 2-2

Figure 3. Dimensional details of the general specimen (dimension: $\mathrm{mm}$ )

All specimens had 150x250-mm window openings on two faces and one 150x400-mm door opening. The thickness of the outer wall was $50 \mathrm{~mm}$ and the thickness of the inner wall was $25 \mathrm{~mm}$. All specimens contained three-compartment. The brick dimensions were 30x50x25 mm. The gypsum-mortar used for the tested specimens was prepared with sand/plaster and water/plaster ratios of 1:2. Production stages of specimens are shown in Figure 4. The different bonds of test specimens are shown in Figure 5. 

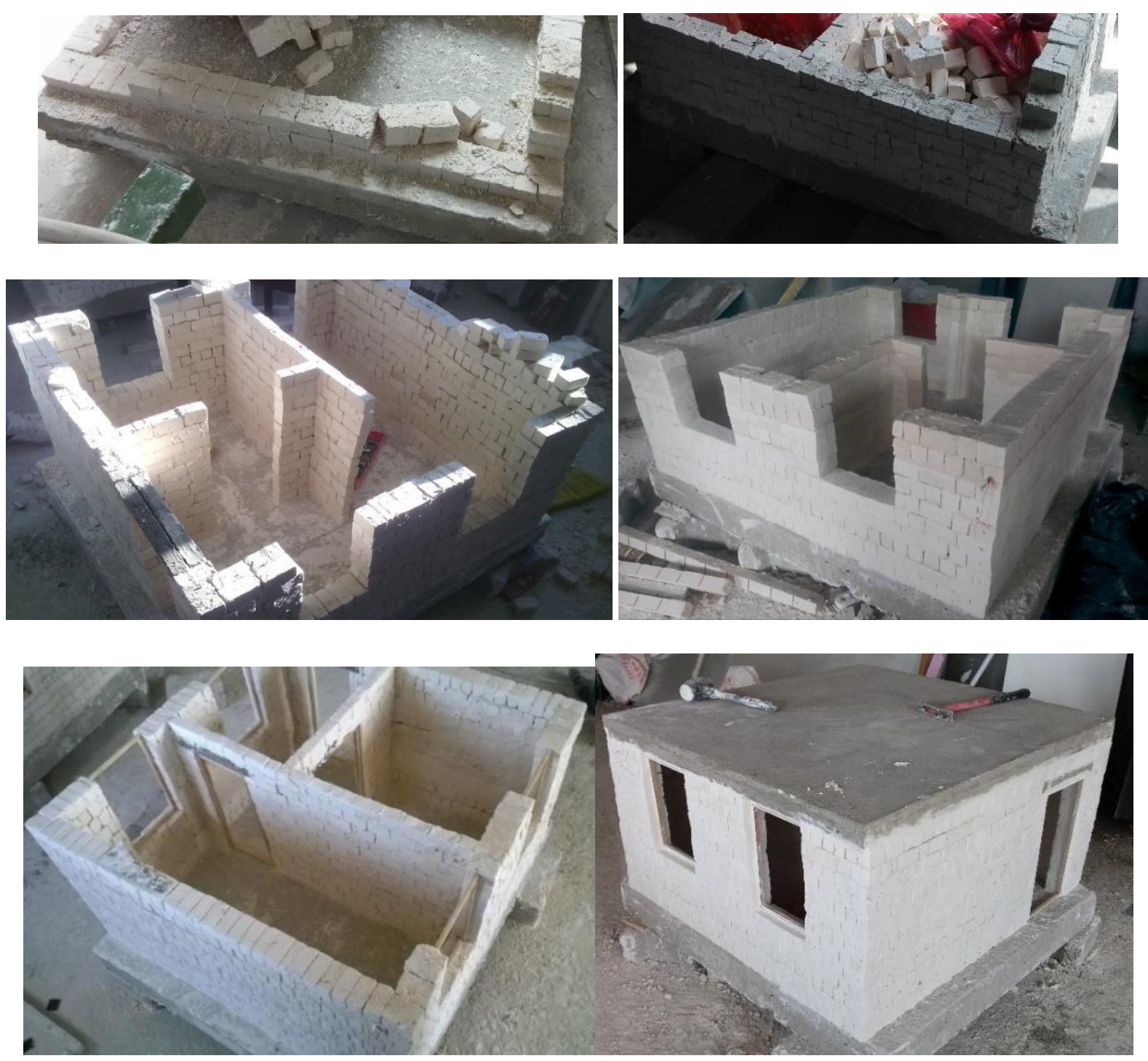

Figure 4. Production stages of specimens 


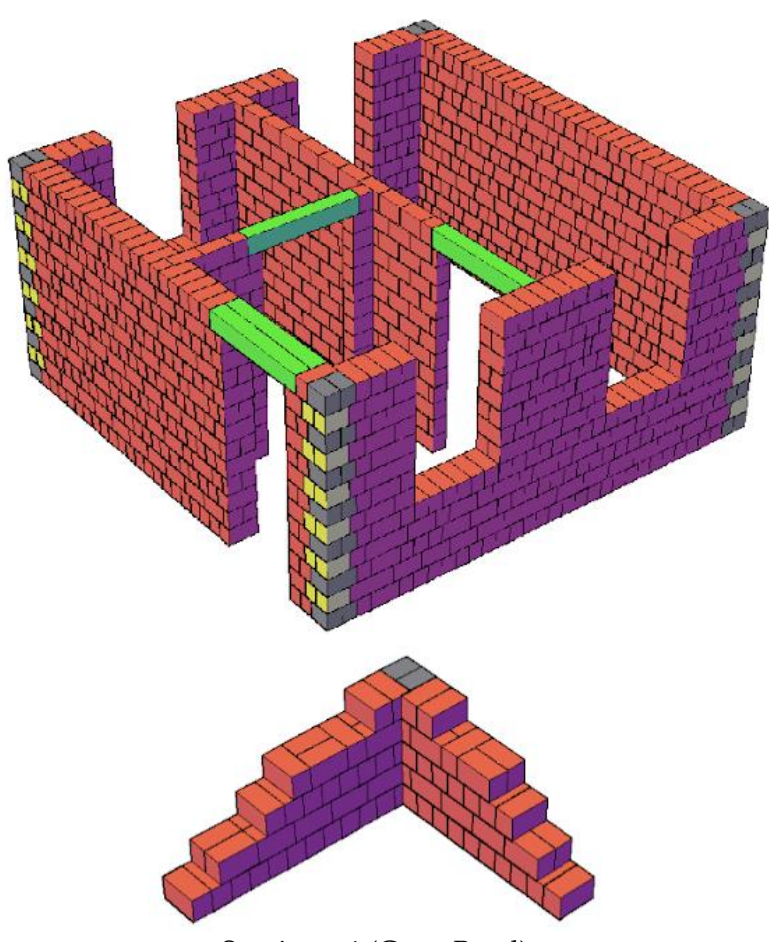

Specimen 1 (Cross Bond)
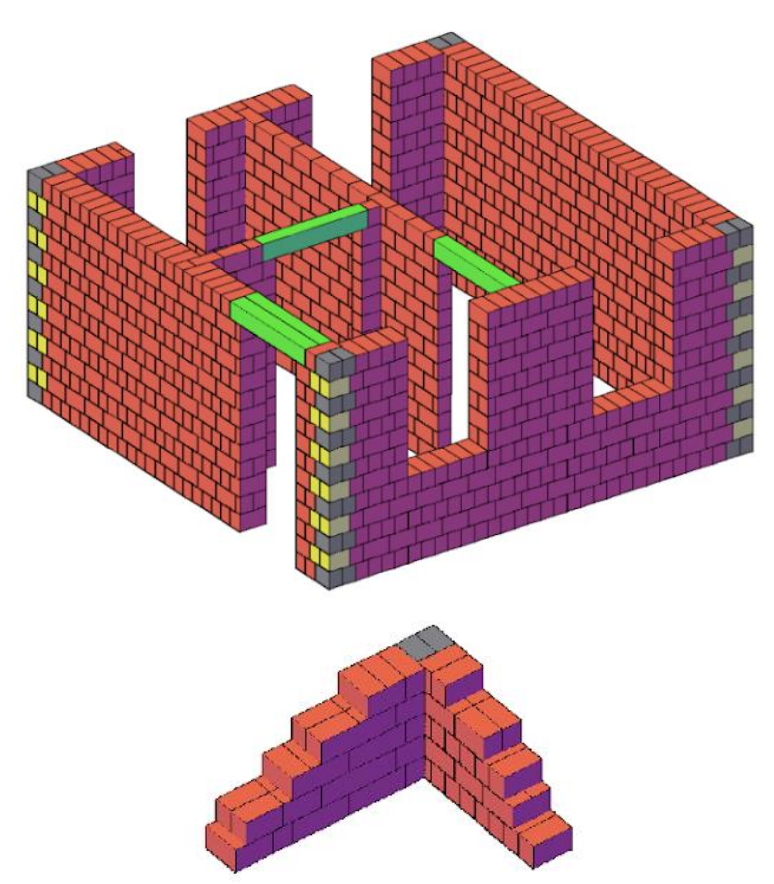

Specimen 3 (English Bond)

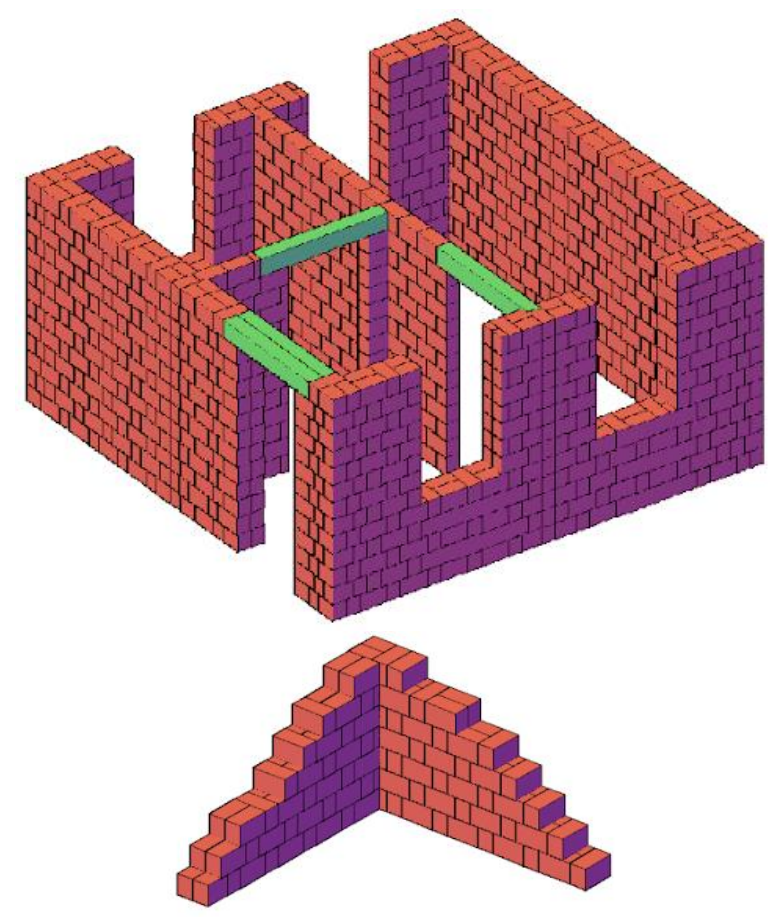

Specimen 2 (Flemish Bond)
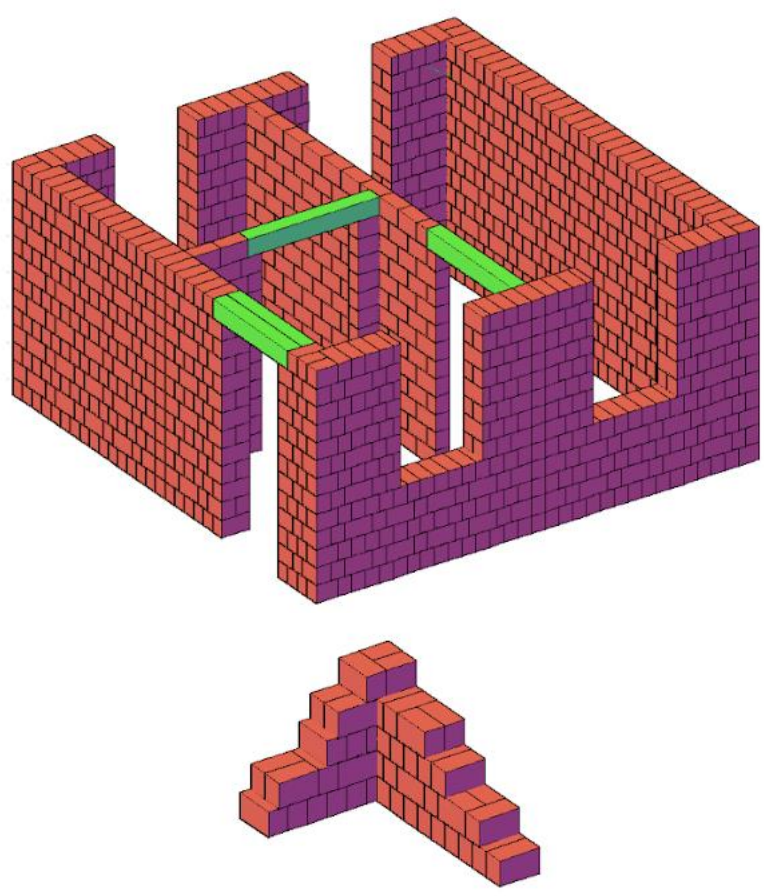

Specimen 4 (Dutch Bond)

Figure 5. Different bonds of Specimens

In infill brick walls of specimens were tested under diagonal compression (Zimmermann et al., 2012, Bahadir et al., 2015, Bahadir et al., 2018; Bahadir, 2020). Due to the non-homogenous structures of the brick walls, it is very difficult to obtain the modulus of elasticity and Poisson ratio using the test data for brick walls. The average diagonal compressive strength of the infill wall was average about 0.65-0.75 MPa.

The scale factors used for measurements and dimensions of specimens on the shake table are given in Table 1. According to the scale laws obtained from Table 1, the same ground motion was applied to specimens in short time periods and high frequencies. 
Table 1. Scale factors for experimental study at shaking tables (Harris et al., 1999; Başaran et al., 2014; Bahadir et al., 2018; Bahadir, 2020).

\begin{tabular}{|c|c|c|}
\hline Parameter & Dimension & Scale Factors \\
\hline Gravitational acceleration, $\mathrm{g}$ & LT-2 & 1 \\
\hline Velocity, $\mathrm{v}$ & $\mathrm{LT}-1$ & $\mathrm{Sl} 1 / 2$ \\
\hline Time, $\mathrm{t}$ & $\mathrm{T}$ & $\mathrm{Sl} / 2$ \\
\hline Linear Dimension, 1 & $\mathrm{~L}$ & $\mathrm{Sl}$ \\
\hline Displacement, $\delta$ & $\mathrm{L}$ & $\mathrm{Sl}$ \\
\hline Frequency, $\omega$ & $\mathrm{T}-1$ & $\mathrm{Sl}-1 / 2$ \\
\hline Area, $\mathrm{A}$ & $\mathrm{L} 2$ & $\mathrm{Sl} 2$ \\
\hline Volume, $\mathrm{V}$ & $\mathrm{L} 3$ & $\mathrm{Sl} 3$ \\
\hline Modulus, $\mathrm{E}$ & FL-2 & 1 \\
\hline
\end{tabular}

\subsection{Test Setup}

The working principle of the shaking table used in experiments is converted from rotary motion to linear motion. The specimens were tested under constant axial load and sinusoidal cyclic were imposed to simulate the seismic action. This axial load of $980 \mathrm{~N}$ was given by the three plates located on top of the specimens. Besides, the sinusoidal cyclics were processed by the DAQ-Card (Labjack-U3) (Labjack, 2015). The acceleration data of ground motion are shown in Figure 6. The test setup for the experimental study is shown in Figure 7.

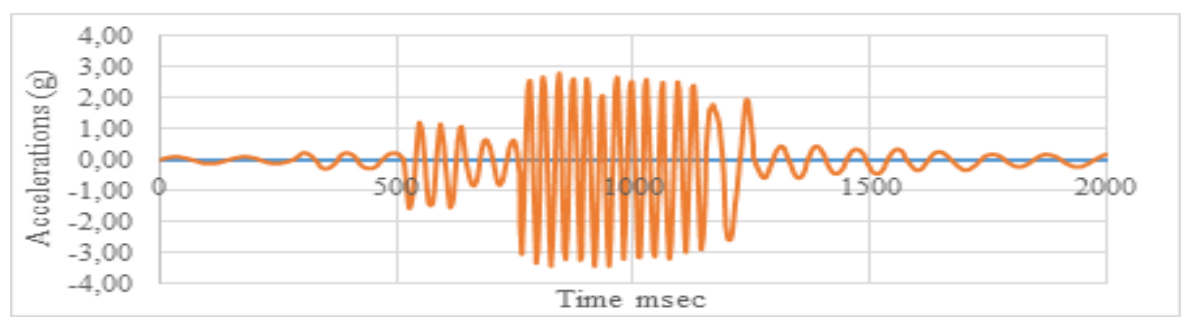

Figure 6. Acceleration data of ground motion

The specimens were tested with a ground motion on the shaking table until failure. Main parameters of the shaking table are given Table 2. 
Table 2. Main parameters of shaking table (Bahadir et al., 2018; Bahadir, 2020)

\begin{tabular}{|l|l|}
\hline Parameters & Values Units \\
\hline Size of the platform & $80 \mathrm{~mm} \times 1200 \mathrm{~mm}$ \\
\hline Maximum mass of load & $15 \mathrm{kN}$ \\
\hline Maximum displacement of the platform & $\pm 20 \mathrm{~mm}$ \\
\hline Maximum acceleration of the platform & $\pm 4 \mathrm{~g}$ \\
\hline Frequency & $0 \sim 50 \mathrm{~Hz}$ \\
\hline Maximum power of motor & $4 \mathrm{~kW}$ \\
\hline Maximum output torque of gear speed reducer & $100518 \mathrm{mNm}$ \\
\hline Maximum input rotational speed of gear speed reducer & $3000 \mathrm{rpm}$ \\
\hline Maximum output rotational speed of gear speed reducer & $380 \mathrm{rpm}$ \\
\hline
\end{tabular}

1.Computer 2. Labjack-U3 3. Simatic-G120 4. Motor+ Gear Speed Reducer 5. Shaking Table Figure 7. Test setup
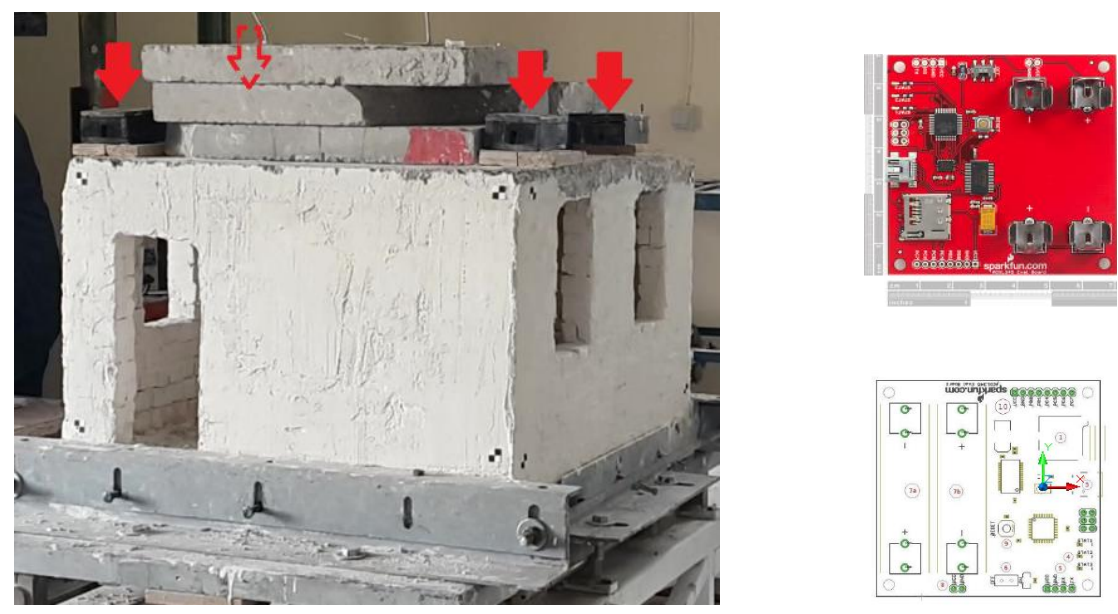

Figure 8. Location points of accelerometers and the ADXL 345 accelerometer

Acceleration data of the test specimens were measured with ADXL345 accelerometers in experiments (Figure 7-8). In the experiments, four accelerometers were used on the specimens and one accelerometer on the shaking table. The average of the accelerometers data on the samples was used in the comparisons. The ADXL345 is a complete 3-axis acceleration measurement system with a selectable measurement range. $\pm 4 \mathrm{~g}$ measurement range was selected in the experiments. It measures both dynamic 
accelerations resulting from motion or shock and static acceleration (ADXL345, 2009). The shake table accelerations were measured at X-direction.

Displacements were calculated using the image processing method. The displacements were measured from the left and the right faces of the prototype structure. The displacements in the experiments were calculated using the Image-Pro v.6 demo version (Image Pro). The camera was calibrated for displacement calculation by image processing before each experiment was performed. These experimental studies have occurred with $\pm 1 \mathrm{~mm}$ margin. A background subtraction method was used for image processing. The application stage of this method is given in Figure 9. This method was used to compare the active image to the background image, and pixels deemed to be part of the background were replaced with a value close to the mean background intensity. The algorithm is based on the following formula:

$$
C I_{x, y}=I_{x, y}-B I_{x, y}+M
$$

$I_{x, y}$ is a pixel value of the original image at the location $(\mathrm{x}, \mathrm{y})$;

$B I_{x, y}$ is a pixel value of the background image at the location $(x, y)$;

$M$ is the average pixel value of the background image;

$C I_{x, y}$ is the new pixel value in the corrected image.

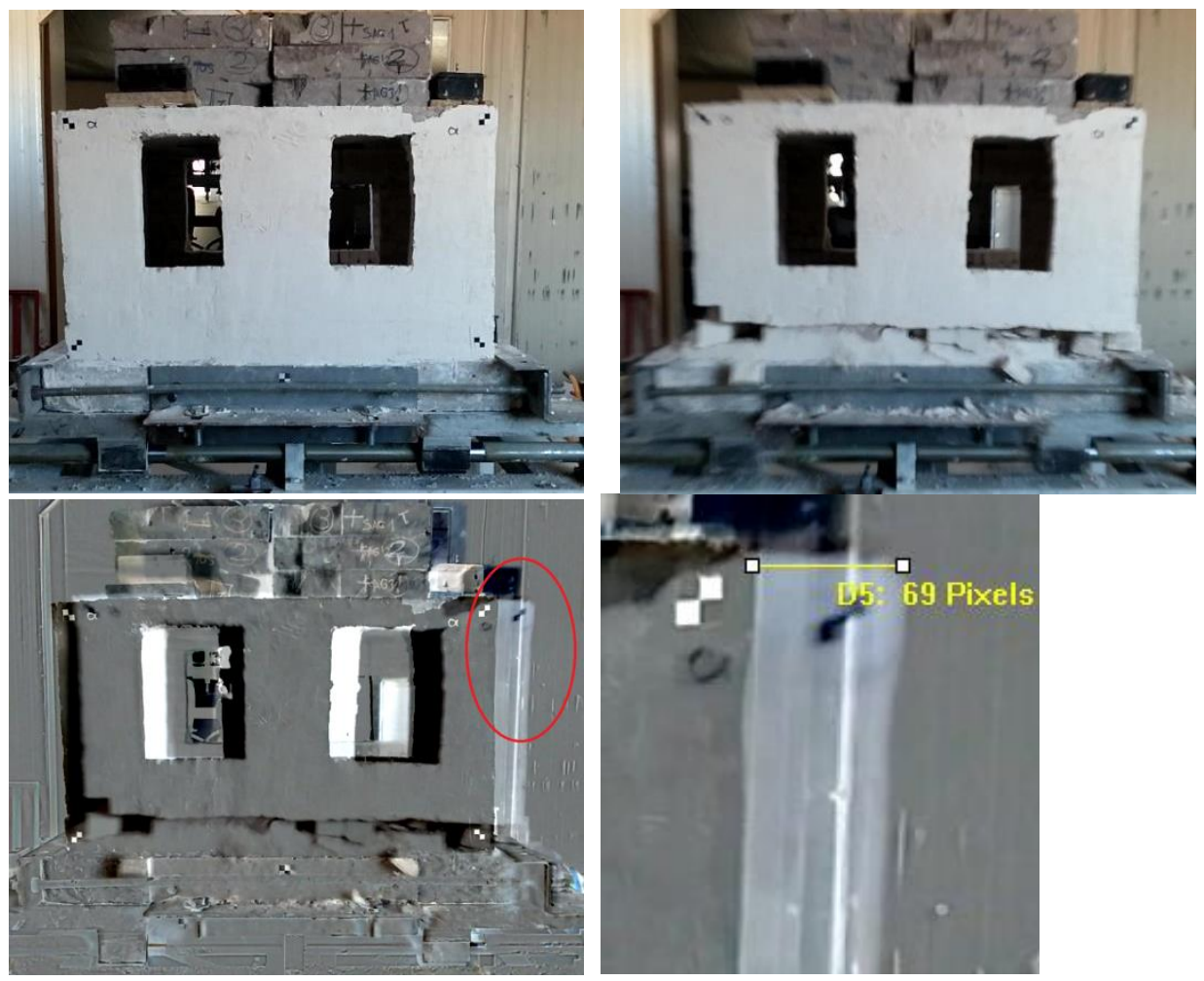

Figure 9. The background subtraction method

\section{RESULT AND DISCUSSION}

\subsection{Experimental results}

Acceleration data of test specimens on the 1st story level at X-direction were measured. The measured acceleration data (Balendra, 1993) of Specimen 1, Specimen 2, Specimen 3, and Specimen 4 are shown in Figure 10, Figure 11, Figure 12, and Figure 13, respectively. First cracks and damages at the failure modes of Specimen 1, Specimen 2, Specimen 3, and Specimen 4 are shown in Figure 14, Figure 15, Figure 16, and Figure 17, respectively. 


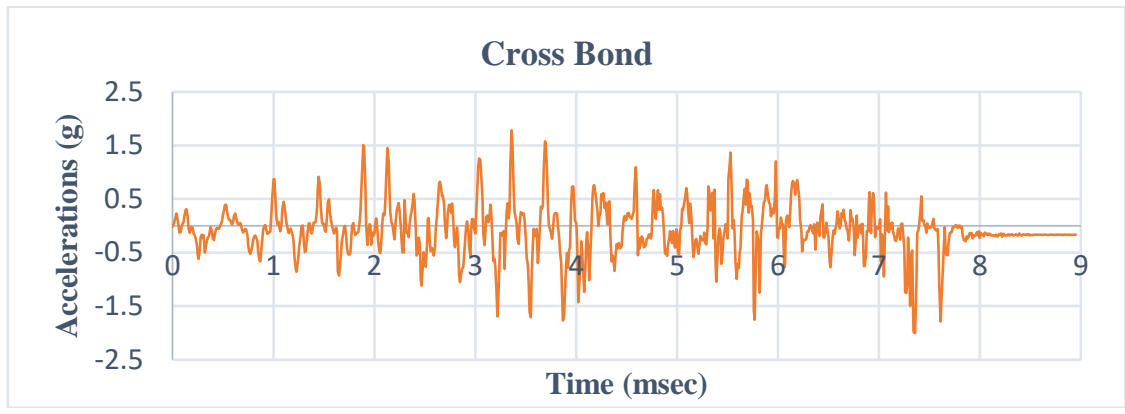

Figure 10. Acceleration data of Specimen 1

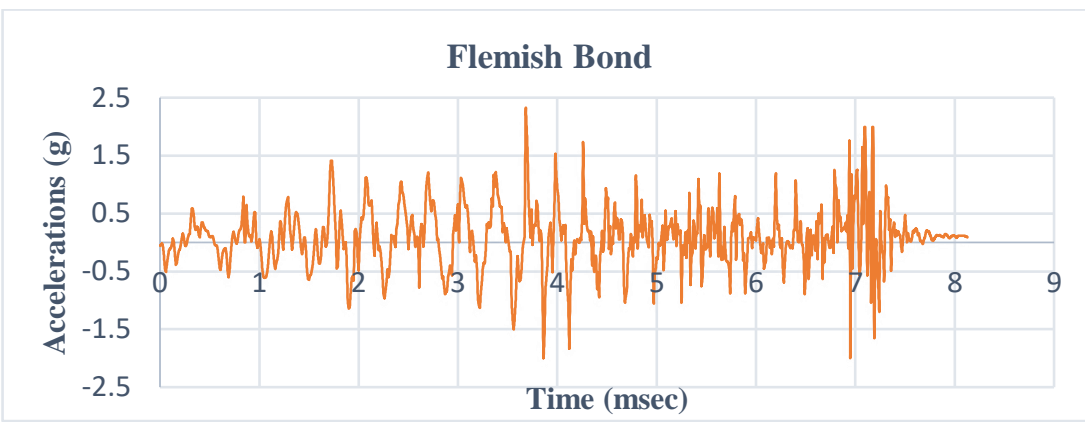

Figure 11. Acceleration data of Specimen 2

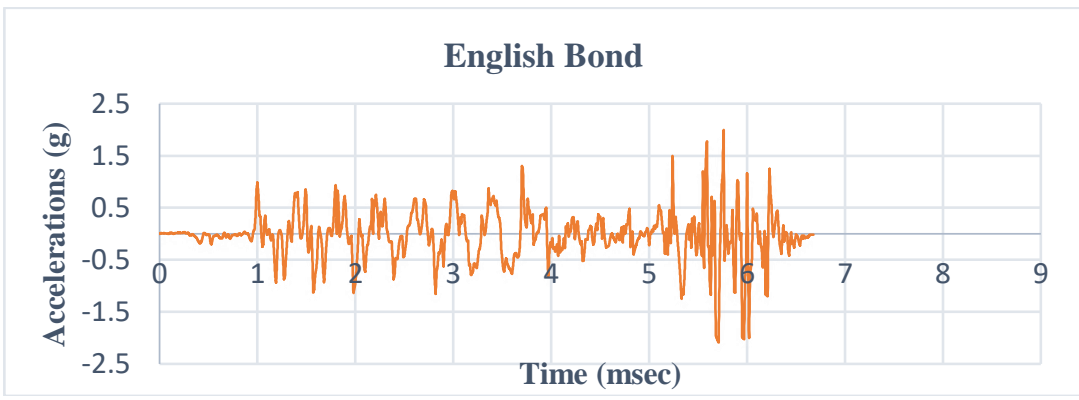

Figure 12. Acceleration data of Specimen 3

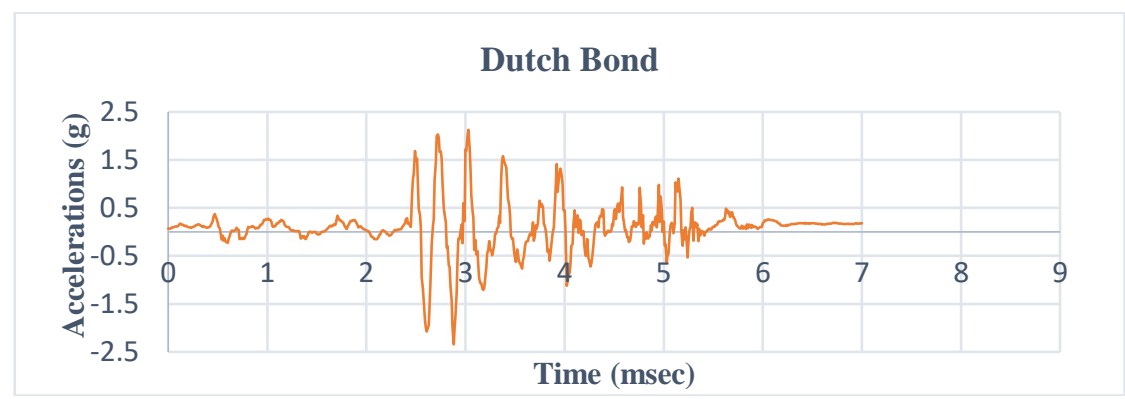

Figure 13. Acceleration data of Specimen 4

In the experimental studies, different types of failure modes and cracks that could occur during the earthquake were observed. The shear and sliding cracks occurred at the windows and door corners. The out-of-plane behavior occurred at the orthogonal wall of the earthquake direction and the walls below the window. The wall between the two windows separating from the slab tried to rotate in a plane and this wall collapsed as out-of-plane. The first cracks of all specimens occurred near the base of the wall (under the windows) as sliding crack. The crack formations of Specimen 1 and Specimen 2 were observed similar. The reason for the longer failure duration of Specimen 1, the first crack occurred later than the other specimens. In addition, the first cracks of Specimen 1, Specimen 2, Specimen 3, Specimen 4 occurred at $4.55 \mathrm{sec}, 2.29 \mathrm{sec}, 3.37 \mathrm{sec}$, and $3.57 \mathrm{sec}$ as sliding cracks, respectively. The shear cracks and other type 
cracks that cause collapse of Specimen 1, Specimen 2, Specimen 3, and Specimen 4 were also begun at 5.39 $\mathrm{sec}, 4.84 \mathrm{sec}, 3.77 \mathrm{sec}, 3.92 \mathrm{sec}$, respectively. According to the obtained results, Specimen 1 and Specimen 2 were more reliable than the other specimens because first and second rows of brick members of these specimens were designed perpendicular to each other at long walls. Due to this design, Specimen 1 and Specimen 2 were later collapsed as other specimens.

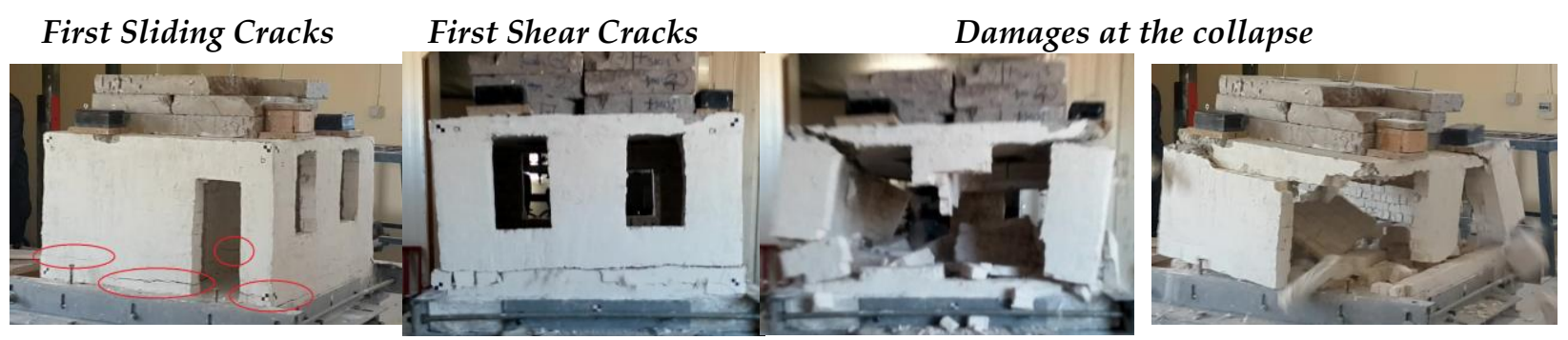

Figure 14. Cracks and damage were observed at the Specimen 1

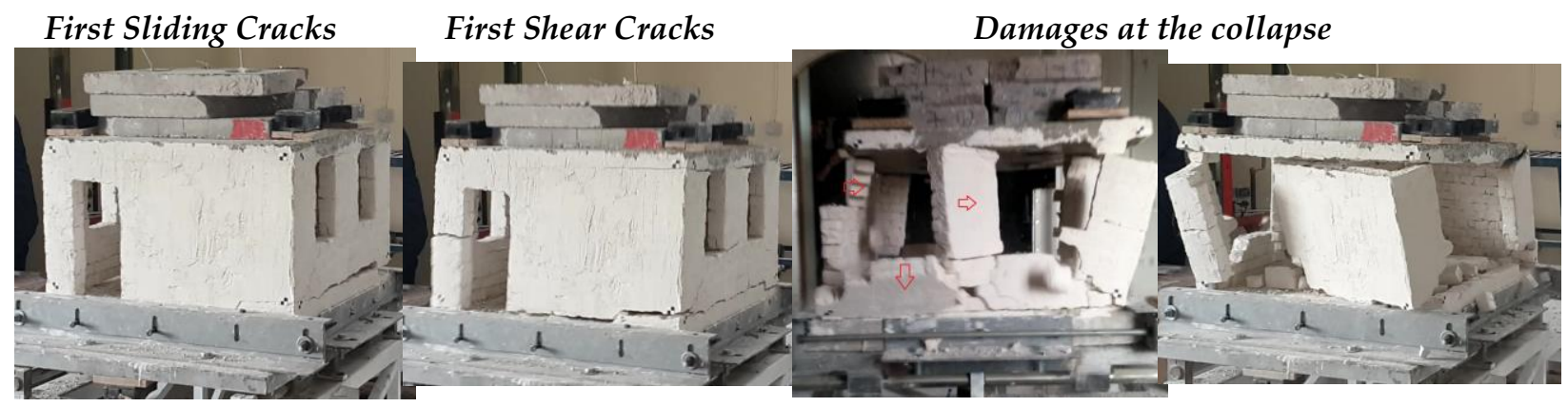

Figure 15. Cracks and damage were observed at the Specimen 2

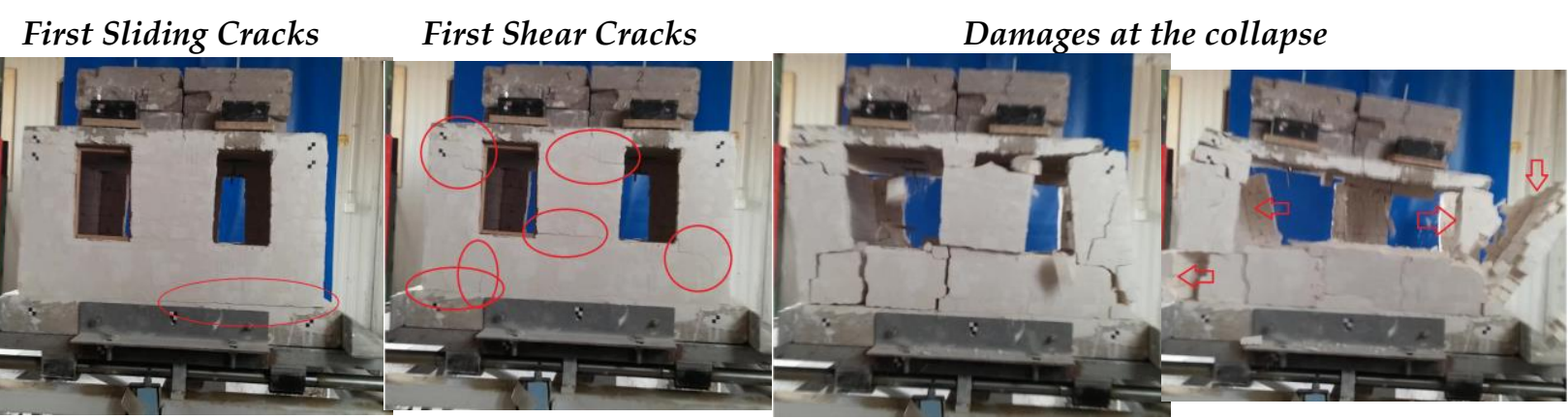

Figure 16. Cracks and damage were observed at the Specimen 3 


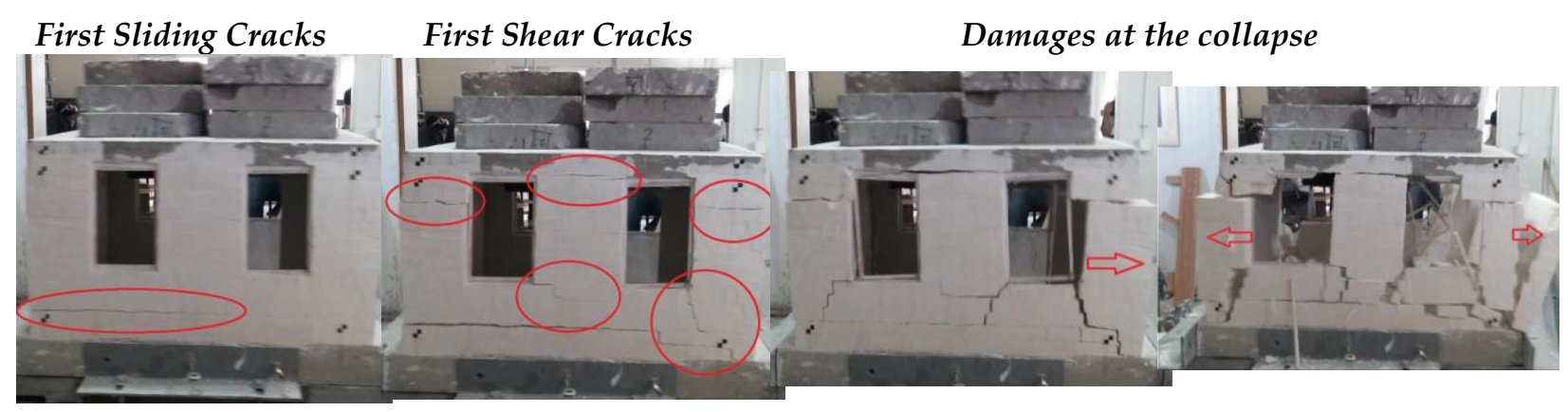

Figure 17. Cracks and damage were observed at the Specimen 4

\section{COMPARISON of TEST RESULTS}

The purpose of the measurement of earthquake motion is to measure acceleration as a function of time or frequency and to observe the behaviors of structures during an earthquake. For this reason, acceleration records constitute an important database for engineering applications and scientific studies.

\subsection{Response Spectrum}

The building exposed to earthquake loads first vibrates during the period that it is subjected to earthquake and then by its own period. If the members of the building do not have damping properties, resonance occurs in the building and causes the building to collapse. The basic items that reduce the period of the building are the weight of the building and irregularities in the building. The exposure of a building to earthquakes at different times can cause the building's period to be greater in the next same magnitude of the earthquake. Because of the vibrations in different periods during the earthquake, the behavior of the building is called the Earthquake Spectrum Graph, which shows the characteristics of the behavior in terms of maximum displacement, acceleration, and velocity. Since Response Spectrum method is useful for approximate evaluation of seismic reliability of structures, this method is favored by earthquake engineering (Balendra, 1993). These graphs of the test specimens are given in Figure 18.

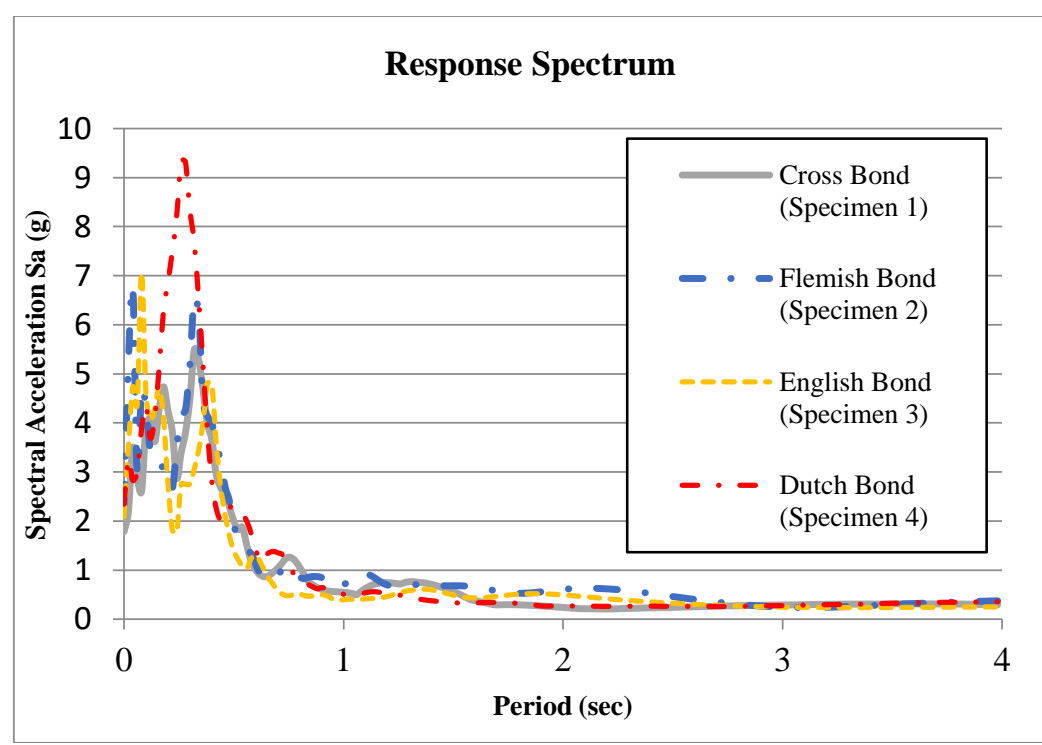

Figure 18. The response spectrum graphs of test specimens by $5 \%$ damping. 
In the analysis of the dynamic behavior of buildings, each earthquake has its own unique acceleration spectrum. According to the natural period and damping rate of the building, the maximum response value obtained from the acceleration response spectrum is the absolute acceleration value which influences the building (Balendra, 1993).

According to the acceleration response spectrums, Specimen 4 occurred to the highest accelerations compared to the other specimens. In addition, Specimen 4 was measured to the largest mean period compared to the other specimens. The mean natural period of Specimen 1 was calculated as 0.276 sec, Specimen 2 was calculated as $0.30 \mathrm{sec}$, Specimen 3 was calculated 0.266, and Specimen 4 was calculated also as $0.324 \mathrm{sec}$. The greater the period value, the greater the amount of damage. In addition, the specimens with a low natural period are more rigid. Specimen 1 has more rigid compared to the other specimens.

\subsection{Displacement of Story}

The displacements were measured from the left and the right faces of the test specimens. At the left face, the maximum displacement of Specimen 1was measured as $-74 \mathrm{~mm}$ at $7.68 \mathrm{sec}$, Specimen 2 was measured as $-52 \mathrm{~mm}$ at $4.63 \mathrm{sec}$, Specimen 3 was measured as $-69 \mathrm{~mm}$ at $4.43 \mathrm{sec}$, and Specimen 4 was also measured $-32 \mathrm{~mm}$ at $4.43 \mathrm{sec}$ (Figure 19). At the right face, the maximum displacement of Specimen 1 was measured as $-68 \mathrm{~mm}$ at $7.35 \mathrm{sec}$, Specimen 2 was measured as $-76 \mathrm{~mm}$ at $4.98 \mathrm{sec}$, Specimen 3 was measured as $-51 \mathrm{~mm}$ at $4.43 \mathrm{sec}$, and Specimen 4 was also measured $-36 \mathrm{~mm}$ at $4.43 \mathrm{sec}$ (Figure 20). At all specimens, the maximum displacements occurred as a negative value. At the maximum displacement of the shaking table, the maximum displacements due to the inertial force of the specimens were measured at negative values. That is, the maximum displacements were formed in the opposite direction to the movement of the shaking table.

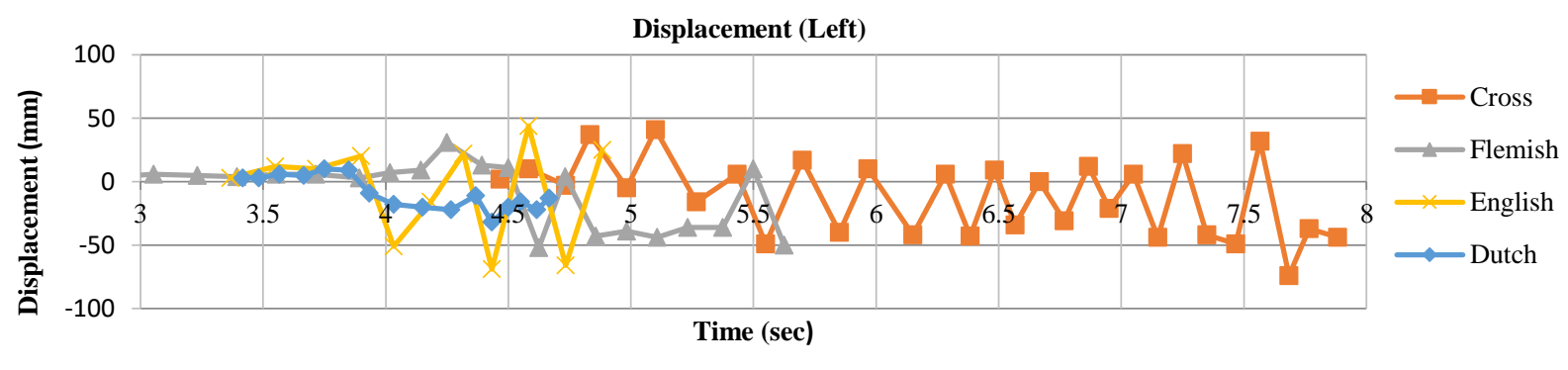

Figure 19. Max displacement of all specimens (left face)

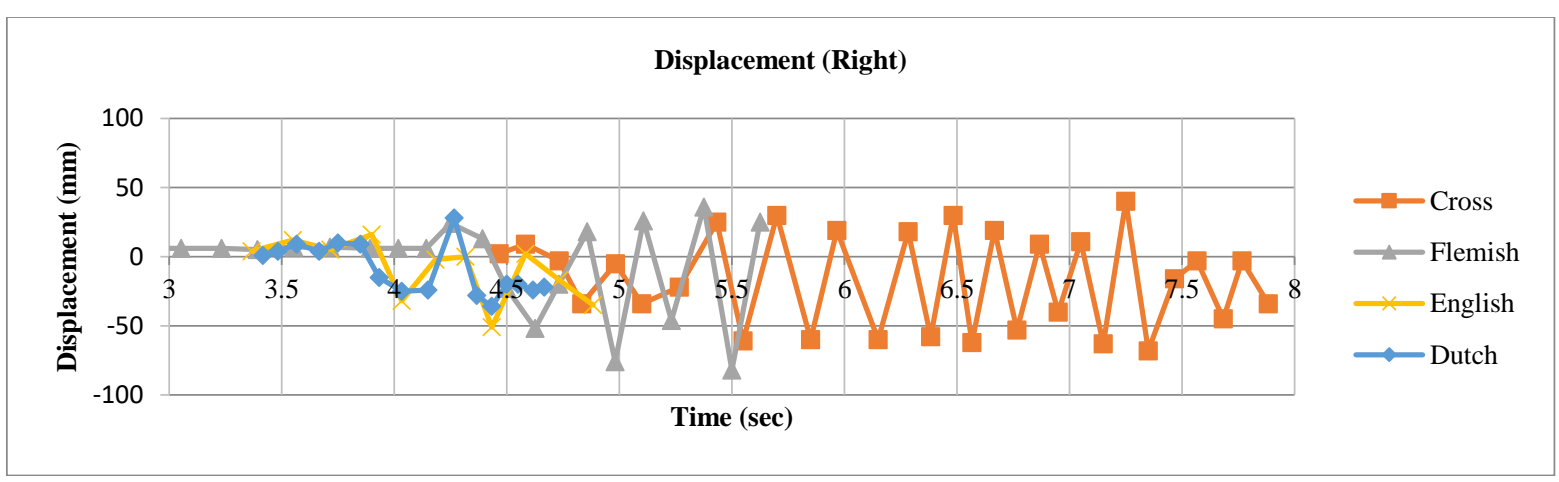

Figure 20. Max displacement of all specimens (right face) 


\subsection{Elastic Seismic Load}

In the analysis of the dynamic behavior of buildings, each earthquake has its own unique acceleration spectrum (Balendra, 1993; Bahadir, 2020). According to the natural period and damping rate of the building, the maximum response value obtained from the acceleration response spectrum is the absolute acceleration value which influences the building. This spectrum is the envelope curve plotted from the peaks of maximum acceleration with the corresponding vibration time $(\mathrm{T})$ of each of singledegree-of-freedom systems. In the spectrum to be used in the calculation of inertia force of the internal forces formed in the structure, the acceleration value to be used is not the total acceleration value $(\ddot{u}(t)+$ $\left.\ddot{u}_{g}(t)\right)$, but the acceleration value $\left(\omega^{2}\right.$ SD) at maximum displacement. This acceleration is called Pseudo Acceleration and this spectrum is called Pseudo Spectral Acceleration (Balendra, 1993). The relationship between pseudo-spectral acceleration and spectrum displacement is given in Equation 2. Under the influence of seismic activities, the building carrier system must be able to withstand at least this elastic seismic load (Equation 3). If the masses of the specimens are approximately the same, these values can be used as a comparison.

$$
\begin{aligned}
& \mathrm{PSA}=\omega^{2} \cdot \mathrm{SD} \\
& F_{e l}=m \cdot P S A
\end{aligned}
$$

$\mathrm{u}(\mathrm{t})$ : Displacement $(\mathrm{u})$ at the $(\mathrm{t})$ time

$\mathrm{u}_{\mathrm{g}}(\mathrm{t})$ : Relative displacement (ug) at the ( $\left.\mathrm{t}\right)$ time

$\omega$ : Angular frequence

SD: Spectral Displacement

PSA: Pseudo Spectral Acceleration (g)

m: Mass

Fel: Elastic seismic load

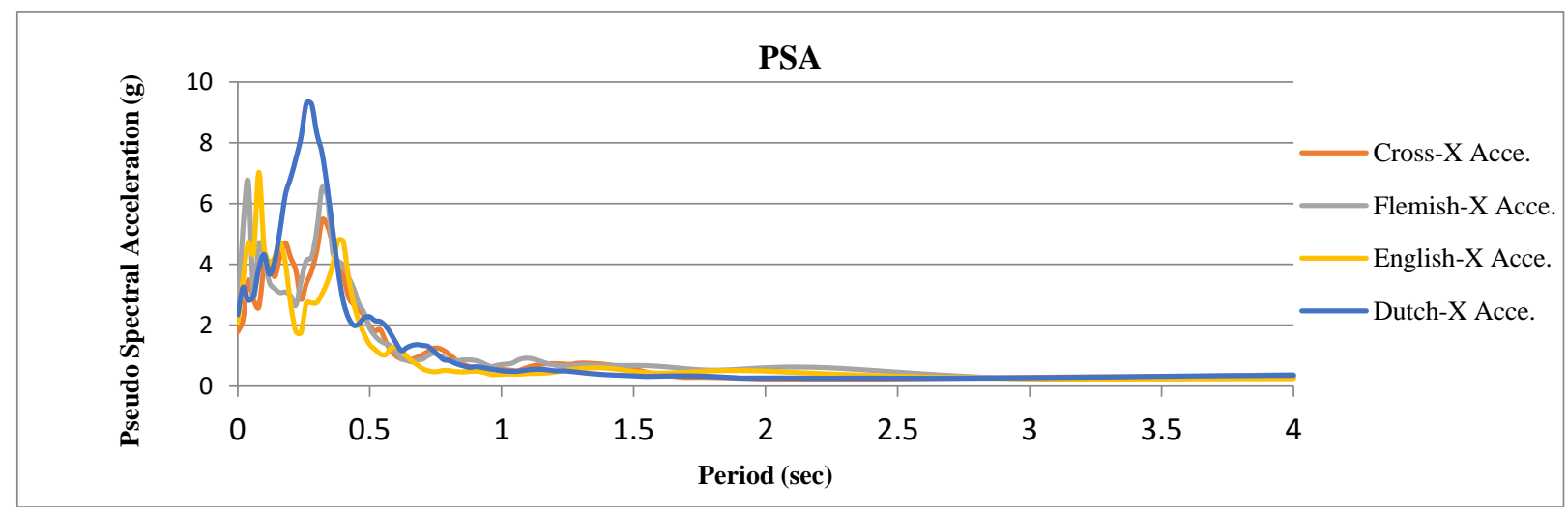

Figure 21. The Response Pseudo Spectral Acceleration graphs of test specimens by $5 \%$ damping.

According to the PSA data obtained from the experiments (Figure 21), Specimen 4 subjected to the highest elastic seismic load compared to the other specimens. This shows that this specimen did not provide the required seismic performance compared to other specimens. Specimen 1 provided the highest seismic performance. The elastic seismic loads of Specimen 2, Specimen 3, and Specimen 4 have increased $1.23,1.29$, and 1.7 times more than Specimen 1 (respectively). 


\section{CONCLUSION}

In this study, the 3D-prototype masonry buildings were tested on the shaking table for the dynamic behavior of the structure. The specimens produced as one story, 3D, three-compartment, 1/6 geometric scale and different wall bonds. The specimens were tested with the same ground motion on the shaking table until the failure mode. Specimen 4 with dutch bond was the lowest seismic performance according to both natural period and elastic seismic loads compared to other specimens. Specimen 1 with cross bond also provided the highest seismic performance. This specimen had more rigid compared to the other specimens. Besides, Specimen 4 has reached its latest collapse state compared to other specimens. When the shear and shear cracks in the test specimens are examined, almost the same failure mechanisms have been formed in all specimens.

All masonry structures that are not carefully manufactured and do not receive engineering services, regardless of the type of the bond, cannot exhibit sufficient earthquake performance. As a result, for the masonry buildings stated in TBSC-2018, vertical lintels can be made on the sides of the door and windows, or the door and window spaces can be made smaller, which can make an important contribution to the seismic performance of masonry buildings. In such existing structures, which have not been built window and door vertically lintels, it is necessary to carry out appropriate strengthening applications to achieve the required earthquake performance.

\section{Data Availability Statement}

All raw data generated or used during the study are available in the DesignSafe-CI repository online in accordance with funder data retention policies. Bahadir, F., (2019-06-07) "Behaviour of Prototype Masonry Buildings Produced with Different Bond on the Shaking Table “. (Bahadir, 2019) DesignSafe-CI. https://doi.org/10.17603/ds2-fm59-xa94

\section{REFERENCES}

Arya, Anand S., Teddy Boen, and Yuji Ishiyama (2014). Guidelines for earthquake resistant nonengineered construction. UNESCO, 2014.

ADXL345 Evaluation Board (2009), https://www.sparkfun.com/datasheets/Sensors/Accelerometer/ADXL345.pdf, 2009

Bahadir F., Balik F.S., (2015). "Seismic Performance Improvement of 3D Reinforced Concrete Frames with Different Strengthening Applications ", Applied Mechanics and Materials Manufacturing Science and Technology VI Chapter: 8 Civil Engineering, 789-790, 1140-1144. doi: 10.4028/www.scientific.net/AMM.789-790.1140

Bahadir, Fatih, and Fatih Süleyman Balik (2018). "Behaviour of 3D RC frames placed at different angles on shaking table." Građevinar70.03. (2018): 171-186. https://doi.org/10.14256/JCE.1655.2016

Bahadir, F., (2019-06-07) "Behaviour of Prototype Masonry Buildings Produced with Different Bond on the Shaking Table ". DesignSafe-CI. https://doi.org/10.17603/ds2-fm59-xa94

Bahadir F. (2020). "Experimental study on three-dimensional reinforced concrete frames subjected to dynamic loading". Structures (24). pp. 835-850 Elsevier. 2020. https://doi.org/10.1016/j.istruc.2020.01.045

Balendra, T. (1993). "Vibration of Buildings to Wind and Earthquake Loads". Springer-Verlag London.1993. ISBN:978-1-4471-2055-1. doi: 10.1007/978-1-4471-2055-1.

Başaran, H., Demir, A., Bağcl, M., \& Ercan, E. (2014). Shaking table study of masonry buildings with reinforced plaster. doi:10.14256/JCE.1036.2014, pp.625-633, 2014

Ersubasi, F., \& Korkmaz, H. H. (2010). "Shaking table tests on strengthening of masonry structures against earthquake hazard." Natural Hazards and Earth System Sciences, 10(6), 1209. doi:10.5194/nhess10-1209-2010, 2010 
Hanazato, T., Minowa, C., Narafu, T., Imai, H., Ali, Q., Kobayashi, K., Nakagawa, T. (2008). “Shaking Table Test of Model House of Brick Masonry for Seismic Construction". In Proceedings of 14th World Conference of Earthquake Engineering (14WCEE).

Harris, Harry G., and Gajanan Sabnis (1999). Structural modeling and experimental techniques. CRC press.1999

Image Pro, https://mediacy.com/imageproplus.

Kamanli, M., \& Balik, F. S. (2010). "The behaviour of roof gable walls under the effect of earthquake load". Natural Hazards and Earth System Sciences, 10(2), 251-263.doi:10.5194/nhess-10-251-2010, 2010.

Labjack U3-HV (2015), https://labjack.com/support/datasheets/u3, 2015.

Leite, J. C., \& Lourenco, P. B. (2012). “Solutions for infilled masonry buildings: shaking table tests". In 15th International Brick and Block Masonry Conference (pp. 1-10). Universidade Federal de Santa Catarina (UFSC).

Rao K. N., Ramesh Babu R. (2012). “Assessment of Seismic Performance of Reinforced SMB Masonry Building Models through Shock Table and Shaking Table Tests ", CiSTUP Indian Institute of Science, Bangalore.

Saito T., Moya L., Fajardo C., and Morita K. (2013). "Experimental Study on Dynamic Behavior of Unreinforced Masonry Walls “, Journal of Disaster Research, 8(2).

Stephen, R. M., Bouwkamp, J. G., Clough, R. W., \& Penzien, J. (1969). "Structural Dynamic Testing Facilities at the University of California, Berkeley". Earthquake Engineering Research Center, College of Engineering, University of California.

Sullivan, T. J., Pinho, R., Pavese, A. (2004), "An Introduction to Structural Testing Techniques". Earthquake Engineering Research Report Rose School, 1.

Turer, A., Korkmaz, S. Z., \& Korkmaz, H. H. (2007). "Performance improvement studies of masonry houses using elastic post-tensioning straps". Earthquake Engineering \& Structural Dynamics, 36(5), 683-705.

Turkish Building Seismic Code (2018) (Ankara: Prime Ministry, Disaster and Emergency Management Presidency (AFAD)) 2018.

Zimmermann, Thomas, and Alfred Strauss (2012). "Masonry and Earthquakes: Material properties, Experimental testing and Design approaches." Earthquake-Resistant Structures-Design, Assessment and Rehabilitation. InTech, 2012. 